\title{
The effects of calcination and doping on structural and dielectric properties of $\mathrm{CaCu}_{3-\mathrm{x}} \mathrm{Co}_{\mathrm{x}} \mathrm{Ti}_{4} \mathrm{O}_{12}$ ceramic
}

\author{
Nasr Hadi ${ }^{1, *}$, Abdi Farid ${ }^{1}$, Tajdine Lamcharfi ${ }^{1}$, Nor-Said Echtoui ${ }^{1}$, Ahmed Harrach ${ }^{2}$, Mohammed \\ Zouhairi ${ }^{2}$ and Fatima Zahra Ahjyaje ${ }^{3}$ \\ ${ }^{1}$ Laboratory of Signals, Systems and Components, USMBA. FST Fez, B.P. 2202, Morocco \\ ${ }^{2}$ Laboratory of Condensed Matter Chemistry, USMBA.FST-Fes, B.P. 2202, Morocco \\ ${ }^{3}$ Laboratory of Materials Natural Substances, Environment and Modeling, LMSNEM, USMBA. FP-Taza. \\ Morocco
}

\begin{abstract}
The influences of calcination temperature and doping with cobalt in A-site on structural and dielectric properties of $\mathrm{CaCu}_{3-\mathrm{x}} \mathrm{Co}_{\mathrm{x}} \mathrm{Ti}_{4} \mathrm{O}_{12}(\mathrm{CCCxTO}, \mathrm{x}=0.00,0.02$ and 0.10$)$ ceramics sintered at $1050{ }^{\circ} \mathrm{C}$ for $8 \mathrm{~h}$ were investigated. The ceramic samples are prepared by the conventional solid-state method using high purity oxide powders, and they are calcined at $850{ }^{\circ} \mathrm{C}, 950{ }^{\circ} \mathrm{C}$ and $1050{ }^{\circ} \mathrm{C}$ for $4 \mathrm{~h}$. The X-ray diffraction (XRD) analysis of pure and doped CCTO samples calcined at $950{ }^{\circ} \mathrm{C}$ and $1050{ }^{\circ} \mathrm{C}$ showed no traces of any other secondary phases, while impurity phases alongside CСТO phase in the $\mathrm{x}=0.00$ sample calcined at $850^{\circ} \mathrm{C}$ was observed. Scanning electron microscopy (SEM) investigation showed an increase in grain size with increasing of Co content and calcining temperature. Dielectric measurements indicated that the dielectric constant of the pure CCTO calcined at $1050{ }^{\circ} \mathrm{C} / 4 \mathrm{~h}$ has a low value in the frequency range of $1 \mathrm{kHz}$ up to $1 \mathrm{MHz}$, whereas the substitution of Co up to $\mathrm{x}=0.10$ into CCTO caused a huge increase in the dielectric constant value of the calcined samples which is equal to 153419 and 18957 at $950{ }^{\circ} \mathrm{C}$ and $1050{ }^{\circ} \mathrm{C}$ respectively. The complex impedance analysis of all samples shows a decrease in resistance with an increasing temperature, which suggests a semiconductor nature of the samples.
\end{abstract}

Keywords: Ceramic, CCTO, Dielectric properties, Doping; Cobalt; $\mathrm{CaCu}_{3-\mathrm{x}} \mathrm{Co}_{\mathrm{x}} \mathrm{Ti}_{4} \mathrm{O}_{12}$; calcination temperature.

\section{Introduction}

There are a great number of applications for ceramic materials due to their giant relative permittivity, electrically insulating and electrical conducting properties. Nowadays, advanced ceramics became the key to success for the development of integrated circuits in microelectronic ${ }^{1,2}$. Calcium copper titanate $\left(\mathrm{CaCu}_{3} \mathrm{Ti}_{4} \mathrm{O}_{12}\right)$ (CCTO) is well known for the treatment of radioactive wastes since these properties form a vast number of solid solutions with rare earth metals ${ }^{3,6} \cdot \mathrm{CaCu}_{3} \mathrm{Ti}_{4} \mathrm{O}_{12}$ based dielectric ceramics have been extensively investigated for their microwave dielectric properties ${ }^{6}$. CCTO exhibits a combination of high permittivity and modest dielectric loss. It has been extensively investigated for their temperature independent dielectric permittivity without a ferroelectric transition over a large temperature range ${ }^{1,7-9}$. These investigations concern the origin of the huge dielectric permittivity.

Numerous theoretical ${ }^{10-12}$ and experimental ${ }^{13-16}$ attempts have been made to understand the extraordinarily high value of the dielectric

*Corresponding author: Nasr Hadi

E-mail adresse: nassarmabbed@hotmail.com DOI: http://dx.doi.org/10.13171/mjc8319052011nh permittivity. Extrinsic and intrinsic origin, and the internal barrier layer capacitor model has been proposed to account for such high $\varepsilon_{\mathrm{r}}{ }^{14-16}$.

Other interesting features observed in $\mathrm{CaCu}_{3} \mathrm{Ti}_{4} \mathrm{O}_{12}$ are the strong nonlinear I-V characteristics ascribed to the intrinsic electrostatic barrier at the grain boundary ${ }^{17,19}$ and optical responses ${ }^{11,12}$. All these properties are controlled by the chemistry of the ceramics.

Hence, $\mathrm{CaCu}_{3} \mathrm{Ti}_{4} \mathrm{O}_{12}$ ceramics were synthesized by different methods and chemically modified by doping to tune the microstructure, grain size, boundary and surfaces, which are the dominant factor to determine the dielectric properties of CCTO ${ }^{14-23}$.

This paper aims to study the effects of calcination temperature and to dope with Cobalt on A-site $(\mathrm{Cu}-$ site) on the microstructure, electrical and dielectric properties of $\mathrm{CaCu}_{3-\mathrm{x}} \mathrm{Co}_{\mathrm{x}} \mathrm{Ti}_{4} \mathrm{O}_{12},\left(\mathrm{CCC}_{\mathrm{x}} \mathrm{TO}\right)$. For this purpose, three sets of $\mathrm{CCC}_{\mathrm{x}} \mathrm{TO}(\mathrm{x}=0.00,0.02$ and $0.10)$ specimens have been prepared at different temperatures of calcination and characterized by $\mathrm{XRD}, \mathrm{SEM}$ and dielectric measurements.

Received February 7, 2019

Accepted March 25, 2019

Published May 20, 2019 


\section{Experimental}

In this work, the solid state method is used to prepare the polycrystalline samples of $\mathrm{CaCu}_{3}$ ${ }_{\mathrm{x}} \mathrm{Co}_{\mathrm{x}} \mathrm{Ti}_{4} \mathrm{O}_{12}$. In this method, the high purity oxide powders of calcium carbonate $\left(\mathrm{CaCO}_{3} .99 .5 \%\right.$, $)$, copper oxide $\left(\mathrm{CuO}, 99.7 \%\right.$, ) cobalt oxide $\left(\mathrm{Co}_{3} \mathrm{O}_{4}\right.$, $99.8 \%$, ) and titanium dioxide $\left(\mathrm{TiO}_{2}, 99.8 \%\right.$, ) were used as starting materials. The raw powders were weighted according to the stoichiometric ratio of $\mathrm{CaCu}_{3-\mathrm{x}} \mathrm{Co}_{\mathrm{x}} \mathrm{Ti}_{4} \mathrm{O}_{12}$ formula based on the following reaction.

$$
\begin{aligned}
& \mathrm{CaCO}_{3}+(3-\mathrm{x}) \mathrm{CuO}+(\mathrm{x} / 3) \mathrm{Co}_{3} \mathrm{O}_{4}+4 \mathrm{TiO}_{2} \Rightarrow \\
& \mathrm{CaCu}_{3-\mathrm{x}} \mathrm{Co}_{\mathrm{x}} \mathrm{Ti}_{4} \mathrm{O}_{12}+\mathrm{CO}_{2} \text { (gas) }
\end{aligned}
$$

The raw powders for each concentration were mixed in an agate mortar for $1 \mathrm{~h}$ and stirred in acetone for $3 \mathrm{~h}$. The mixed powders at concentrations of $\mathrm{x}=0.00$ were calcined in air at $850{ }^{\circ} \mathrm{C}, 950{ }^{\circ} \mathrm{C}$ and $1050{ }^{0} \mathrm{C}$ for $4 \mathrm{~h}$, while the doped powders $(\mathrm{x}=0.02$ and 0.10$)$ were calcined at $950{ }^{\circ} \mathrm{C}$ and $1050{ }^{\circ} \mathrm{C}$ for 4h. All calcined powders were then pressed into the $1.5 \mathrm{~mm}$ thickness and $12 \mathrm{~mm}$ diameter pellets using polyvinyl alcohol (PVA) as a binder. The final sintering of the pellets was performed at $1050{ }^{\circ} \mathrm{C}$ for $8 \mathrm{~h}$ using a heating rate of $3^{\circ} \mathrm{C} / \mathrm{min}$.

\section{Results and Discussion}

In general, the primary objective of the calcination is to complete the solid-state reaction to form the CCTO ceramic from the raw materials. XRD can confirm the completion of the calcining process. Fig 1. shows the XRD patterns of $\mathrm{CCC}_{0.00} \mathrm{TO}$ powder calcined at $850{ }^{\circ} \mathrm{C}, 950{ }^{\circ} \mathrm{C}$ and $1050{ }^{\circ} \mathrm{C}$ for 4 h. For $\mathrm{CCC}_{0.00} \mathrm{TO}$ calcined at $850{ }^{\circ} \mathrm{C}$, the XRD analysis showed the formation of CCTO phase with the existence of a small amounts of $\mathrm{CuO}, \mathrm{TiO}_{2}$ and $\mathrm{CaTiO}_{3}$ phases, this indicates that the reaction was not complete after calcination at $850{ }^{\circ} \mathrm{C}$, while the $\mathrm{CCC}_{0.00}$ TO samples calcined at $950{ }^{\circ} \mathrm{C}$ and $1050{ }^{\circ} \mathrm{C}$ show a single CCTO phase.

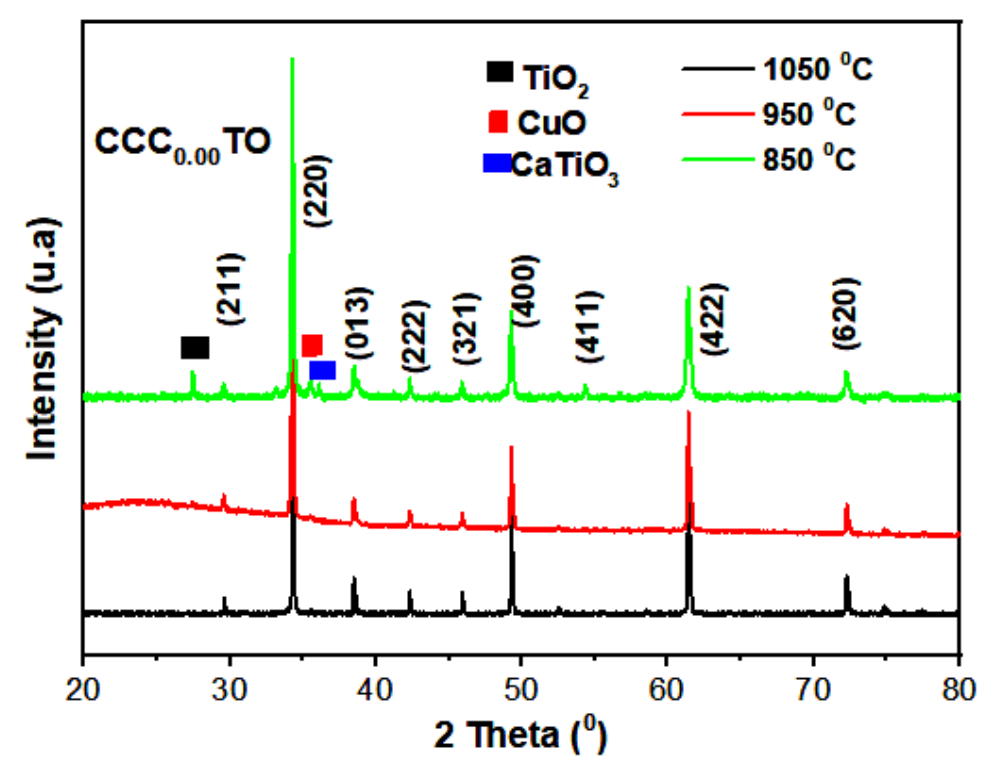

Figure 1. XRD patterns of the $\mathrm{CCC}_{0.00}$ TO samples calcined at 850,950 and $1050{ }^{\circ} \mathrm{C}$ for $4 \mathrm{~h}$

The X-ray diffraction data have been analyzed by employing the Rietveld method using Fullprof software ${ }^{24}$ and Im-3 space group for $\mathrm{CCC}_{0.00} \mathrm{TO}$. The $\mathrm{X}$-ray diffraction patterns and Rietveld refined data are presented in Fig. $2 \mathrm{a}$ and $\mathrm{b}$. In these figures, the black points represent our observed results, and the solid red line represents Rietveld refined data. The bottom line shows the difference between the experimental and refined data. The small vertical blue lines represent Bragg positions allowed. Rietveld analysis confirms the formation of the pure bodycentred cubic perovskite-related structure of space group Im3 and the unit cell parameters were calculated. The lattice parameters obtained of pure $\mathrm{CCC}_{0.00} \mathrm{TO}$ at $950{ }^{0} \mathrm{C}$ and $\mathrm{CCC}_{0.00} \mathrm{TO}$ at $1050{ }^{0} \mathrm{C}$ (Table 1) are in good agreement with those reported in literature ${ }^{7,8}$, Rietveld refinement results show that the crystal structure and lattice parameters do not change when the temperature of calcination changes from $950{ }^{\circ} \mathrm{C}$ to $1050{ }^{\circ} \mathrm{C}$ for $4 \mathrm{~h}$.

The average crystallite size was estimated employing the peaks corresponding to the Bragg's angles ( $2 \theta$ from $20^{\circ}$ to $80^{\circ}$ ) for all samples by using Scherrer's formula and the results are given in Table 1. It can be observed that the crystallite size increases with the increasing the temperature of calcination, which may indicate the increasing rate of crystallites formation $^{25}$.

The quality factors from Rietveld refinement of the observed data have been assessed by computing the parameters such as the $\chi^{2}$ (quality of fit), $R_{B}$ (Bragg factor) and $\mathrm{R}_{\mathrm{F}}$ (structure factor) and are listed in Table1. 

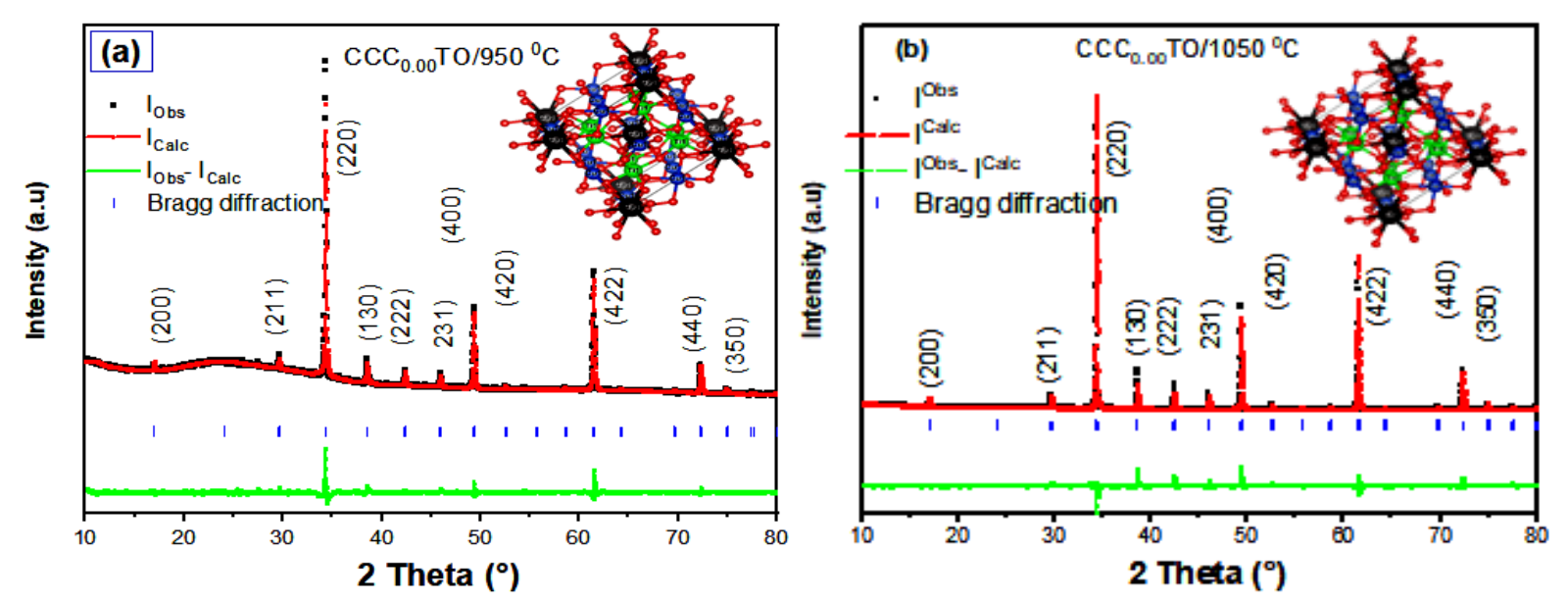

Figure 2. Rietveld refined XRD pattern of; a) CCTO/950 ${ }^{\circ} \mathrm{C}$ and b) $\mathrm{CCTO} / 1050{ }^{\circ} \mathrm{C}$ sample

Table 1. Reliability factors $\left(\mathrm{R}_{\mathrm{Bragg}}, \mathrm{R}_{\mathrm{F}}\right.$ and $\left.X^{2}\right)$, crystalline size $\mathrm{D}$, lattice parameters and cell volume for the $\mathrm{CCTO} / 950{ }^{\circ} \mathrm{C}$ and CCTO $/ 1050{ }^{\circ} \mathrm{C}$.

\begin{tabular}{|l|c|c|}
\hline Parameters & $\mathbf{C C C}_{\mathbf{0 . 0 0}} \mathbf{T O} / \mathbf{9 5 0} \mathbf{C}$ & $\mathbf{C C C}_{\mathbf{0 . 0 0}} \mathbf{T O}_{\mathbf{~ 1 0 5 0}} \mathbf{~} \mathbf{C}^{\circ}$ \\
\hline $\mathrm{R}_{\mathrm{Bragg}}$ & 1.39 & 6.31 \\
\hline $\mathrm{R}_{\mathrm{F}}$ & 4.13 & 7.98 \\
\hline$X^{2}$ & 1.30 & 2.19 \\
\hline $\mathrm{D}(\AA)$ & 545.260 & 983.137 \\
\hline Lattice parameters $(\AA)$ & $\mathrm{a}=\mathrm{b}=\mathrm{c}=7.391$ & $\mathrm{a}=\mathrm{b}=\mathrm{c}=7.391$ \\
\hline $\mathrm{V}\left(\AA^{3}\right)$ & 403.817 & 403.665 \\
\hline
\end{tabular}

The XRD patterns of the $\mathrm{CaCu}_{2.98} \mathrm{Co}_{0.02} \mathrm{Ti}_{12}$ and $\mathrm{CaCu}_{2.90} \mathrm{Co}_{0.10} \mathrm{Ti}_{12}$ ceramics calcined at $950{ }^{\circ} \mathrm{C}$ and $1050{ }^{\circ} \mathrm{C}$ for $4 \mathrm{~h}$ are shown in Fig. 3. These XRD patterns are identical to the un-doped $\mathrm{CCC}_{0.00} \mathrm{TO}$ ones, and confirm the formation of a pure cubic phase of CCCTO at the considered calcination temperatures (Fig. 3a). All diffraction peaks could be indexed by a body-centred cubic related structure of space group

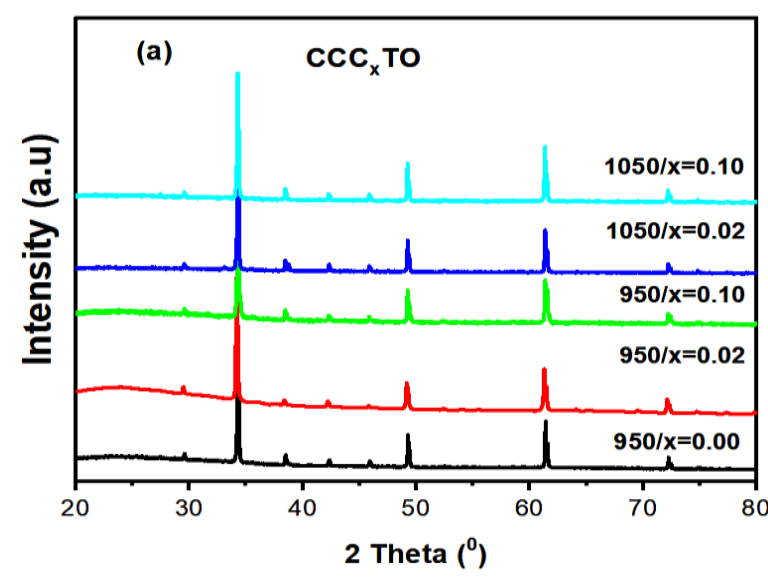

Im-3 according to (JCPDS75-2188). This indicates that the crystal structure of CCTO remains unchanged. The magnified view of the intense peak of CCCTO (220) shows an observable shift of the peak position toward the lower angles for the Codoped samples indicating the solubility of the Cobalt in calcium copper titanate (Fig. 3b).

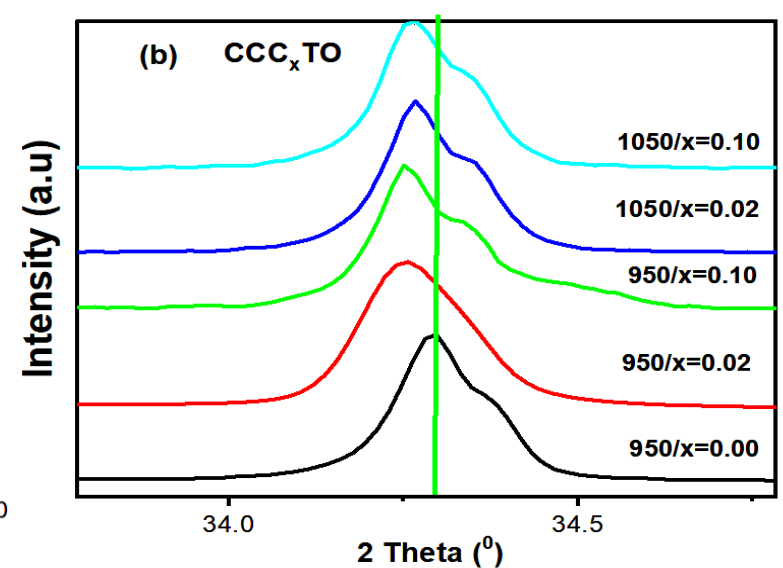

Figure 3. XRD patterns of the $\mathrm{CCC}_{0.00} \mathrm{TO}$ samples calcined at $950{ }^{\circ} \mathrm{C}$ and $\mathrm{CCC}_{0.02} \mathrm{TO}$ and $\mathrm{CCC}_{0.10} \mathrm{TO}$ calcined at 950 and $1050{ }^{\circ} \mathrm{C}$

The Rietveld refinement results for $\mathrm{CCC}_{\mathrm{x}} \mathrm{TO}$ $(\mathrm{x}=0.02,0.10)$ powders calcined at $950{ }^{\circ} \mathrm{C}$ and 1050 ${ }^{0} \mathrm{C}$ for $4 \mathrm{~h}$ are presented in Fig. 4 and Fig. $5 \mathrm{f}$ respectively. It is noticed that the fitted XRD pattern agrees well with the measured data with no structural phase transition from cubic one. Thus, Co 
substitution (with $\mathrm{x} \leq 10 \%$ ) at the calcination temperatures considered in this study does not affect the crystalline structure of the parent compound $\mathrm{CCC}_{0,00} \mathrm{TO}$; this is important for the paraelectric properties of the compounds characterized by a high dielectric constant. The calculated parameters of $\mathrm{CCC}_{\mathrm{x}} \mathrm{T}(\mathrm{x}=0.02,0.10)$ ceramics, calcined at $950{ }^{\circ} \mathrm{C}$

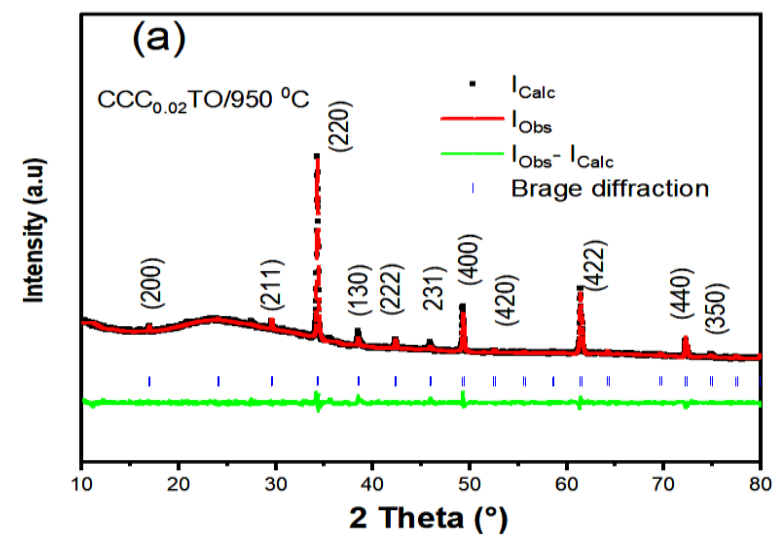

and $1050{ }^{\circ} \mathrm{C}$ were found after refinement to be in Im3 space group and are listed in Table 2 and Table 3. We can see from the results that the lattice parameters values of $\mathrm{CCC}_{0.00} \mathrm{TO}$ increase with increasing $\mathrm{Co}$ dopant concentration at each calcination temperature as well as with increasing calcination temperature for each sample.

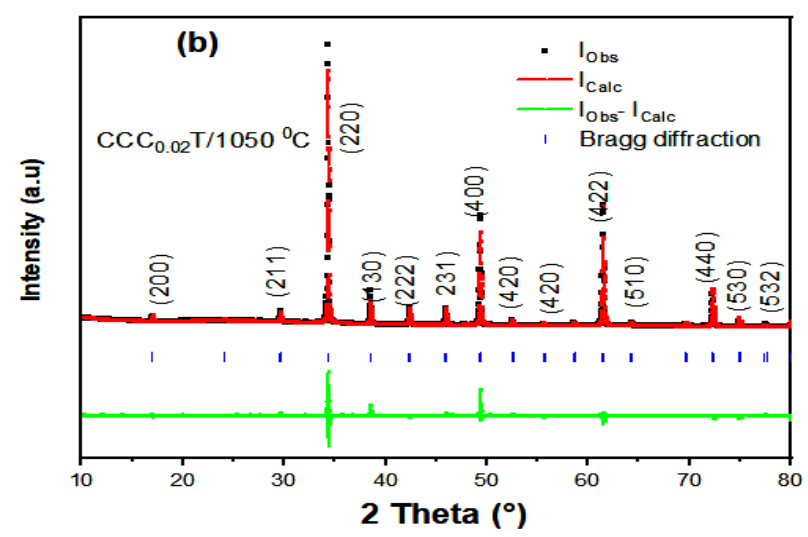

Figure 4. Rietveld refined XRD pattern for the $\mathrm{CCC}_{0.02} \mathrm{TO}$ samples calcined for $4 \mathrm{~h}$ at; a) $950{ }^{\circ} \mathrm{C}$ and $\left.\mathbf{b}\right) 1050{ }^{\circ} \mathrm{C}$

Table 2. Reliability factors $\left(\mathrm{R}_{\mathrm{Bragg}}, \mathrm{R}_{\mathrm{F}}\right.$ and $\left.X^{2}\right)$, crystalline size $\mathrm{D}$, lattice parameters and cell volume for $\mathrm{CCC}_{0.02} \mathrm{TO} / 950{ }^{\circ} \mathrm{C}$ and $\mathrm{CCC}_{0.02} \mathrm{TO} / 1050{ }^{\circ} \mathrm{C}$.

\begin{tabular}{|l|c|c|}
\hline Parameters & $\mathbf{C C C}_{\mathbf{0 . 0 2}} \mathbf{T O} / \mathbf{9 5 0}{ }^{\mathbf{0}} \mathbf{C}$ & $\mathbf{C C C}_{\mathbf{0 . 0 2}} \mathbf{T O} / \mathbf{1 0 5 0}{ }^{\mathbf{0}} \mathbf{C}$ \\
\hline $\mathrm{R}_{\text {Bragg }}$ & 5.09 & 6.70 \\
\hline $\mathrm{R}_{\mathrm{F}}$ & 4.06 & 5.19 \\
\hline$X^{2}$ & 1.68 & 6.20 \\
\hline $\mathrm{D}(\AA)$ & 281.013 & 910.843 \\
\hline Lattice parameters $(\AA)$ & $\mathrm{a}=\mathrm{b}=\mathrm{c}=7.392$ & $\mathrm{a}=\mathrm{b}=\mathrm{c}=7.391$ \\
\hline $\mathrm{V}\left(\AA^{3}\right)$ & 403.911 & 403.567 \\
\hline
\end{tabular}
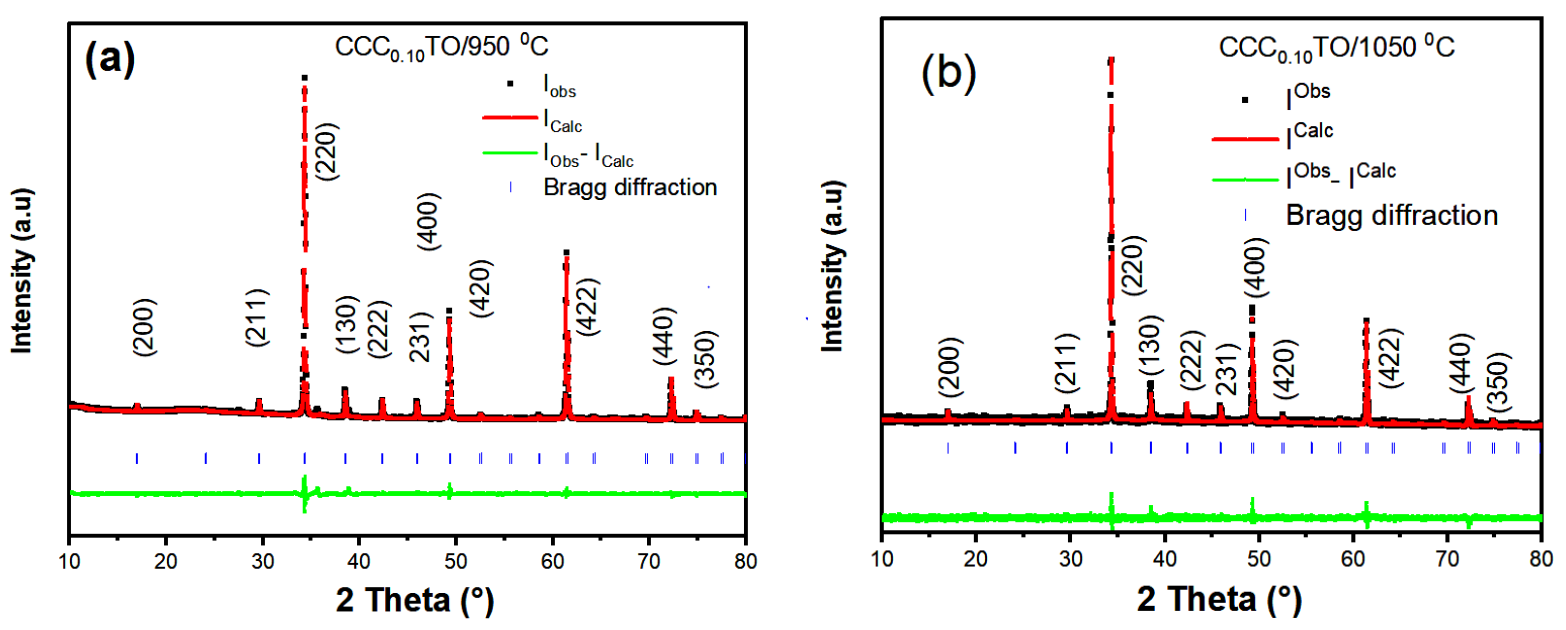

Figure 5. Rietveld refined XRD pattern for the $\mathrm{CCC}_{0.10} \mathrm{TO}$ samples calcined for $4 \mathrm{~h}$ at; a) $950{ }^{0} \mathrm{C}$ and b) $1050{ }^{\circ} \mathrm{C}$.

Table 3. Reliability factors $\left(\mathrm{R}_{\mathrm{Bragg}}, \mathrm{R}_{\mathrm{F}}\right.$ and $\left.X^{2}\right)$, crystalline size $\mathrm{D}$, lattice parameters and cell volume for $\mathrm{CCC}_{0.10} \mathrm{TO} / 950{ }^{\circ} \mathrm{C}$ and $\mathrm{CCC}_{0.10} \mathrm{TO} / 1050{ }^{\circ} \mathrm{C}$. 


\begin{tabular}{|l|c|c|}
\hline Parameters & $\mathbf{C C C}_{\mathbf{0 . 1 0}} \mathbf{T O} / \mathbf{9 5 0}{ }^{\circ} \mathbf{C}$ & $\mathbf{C C C}_{\mathbf{0 . 1 0}} \mathbf{T O}^{\mathbf{1 0 5 0}}{ }^{\circ} \mathbf{C}$ \\
\hline $\mathrm{R}_{\text {Bragg }}$ & 2.27 & 10.8 \\
\hline $\mathrm{R}_{\mathrm{F}}$ & 3.29 & 13.9 \\
\hline$X^{2}$ & 2.39 & 1.21 \\
\hline $\mathrm{D}(\AA)$ & 576.104 & 929.412 \\
\hline Lattice parameters $(\AA)$ & $\mathrm{a}=\mathrm{b}=\mathrm{c}=7.393$ & $\mathrm{a}=\mathrm{b}=\mathrm{c}=7.397$ \\
\hline $\mathrm{V}\left(\AA^{3}\right)$ & 404.070 & 404.781 \\
\hline
\end{tabular}

Fig. 6 shows the micrographs of $\mathrm{CCC}_{0.00} \mathrm{TO}$ ceramics calcined at $950{ }^{\circ} \mathrm{C} / 4 \mathrm{~h}$ and $1050{ }^{\circ} \mathrm{C} / 4 \mathrm{~h}$. It is evident that the morphologies obtained are not uniform. They consist of large grains with sizes more than $13 \mu \mathrm{m}$ and $23 \mu \mathrm{m}$ for $\mathrm{CCC}_{0.00} \mathrm{TO}$ at $950{ }^{\circ} \mathrm{C}$ and $\mathrm{CCC}_{0.00} \mathrm{TO}$ at $1050{ }^{\circ} \mathrm{C}$ respectively, and fine grains

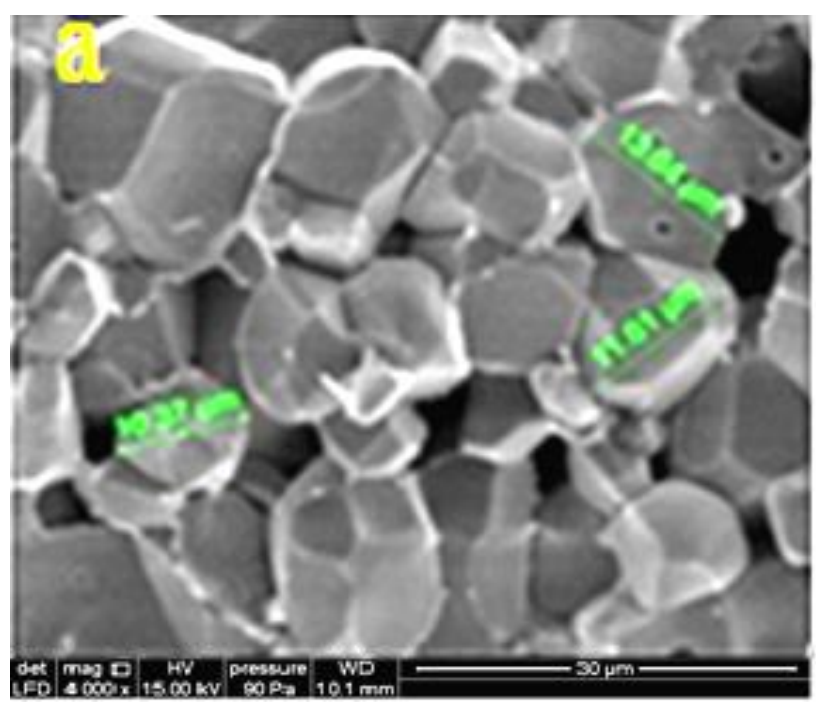

Figure 6. The SEM micrographs of $\mathrm{CCC}_{0.00} \mathrm{TO}$ powders calcined at 950 and $1050{ }^{\circ} \mathrm{C}$ for $4 \mathrm{~h}$.

Fig. $7 \mathrm{a}-\mathrm{c}$ shows the microstructure of $\mathrm{CCC}_{\mathrm{x}} \mathrm{TO}$ pellets surfaces $(x=0.00,0.02$ and 0.10$)$ sintered at $1050{ }^{\circ} \mathrm{C}$ for $8 \mathrm{~h}$ obtained from powders calcined at $1050{ }^{\circ} \mathrm{C}$ for $4 \mathrm{~h}$. Loosely linked grains characterize the morphology of the $\mathrm{CCC}_{0.00} \mathrm{TO} / 1050{ }^{\circ} \mathrm{C}$ sample with a size ranging from $2 \mu \mathrm{m}$ to $23 \mu \mathrm{m}$. For the $\mathrm{CCC}_{0.02} \mathrm{TO}$ sample, the grain size increases (Fig.7b). This sample has a microstructure consisting of some large grains $(6 \mu \mathrm{m}-26 \mu \mathrm{m})$, surrounded by small ones. The surface of the samples doped with $x=0.10$ is characterized by close packing of the grains with sizes lying between $8 \mu \mathrm{m}$ and $30 \mu \mathrm{m}$ (Fig. $7 \mathrm{c}$ ). The with sizes less than $5 \mu \mathrm{m}$ and $2 \mu \mathrm{m}$ respectively. The increasing of temperature of calcination from $950{ }^{\circ} \mathrm{C}$ to $1050{ }^{\circ} \mathrm{C}$ leads to an increase of grain boundaries clarity, the grain size and a change in the shape of the grain.

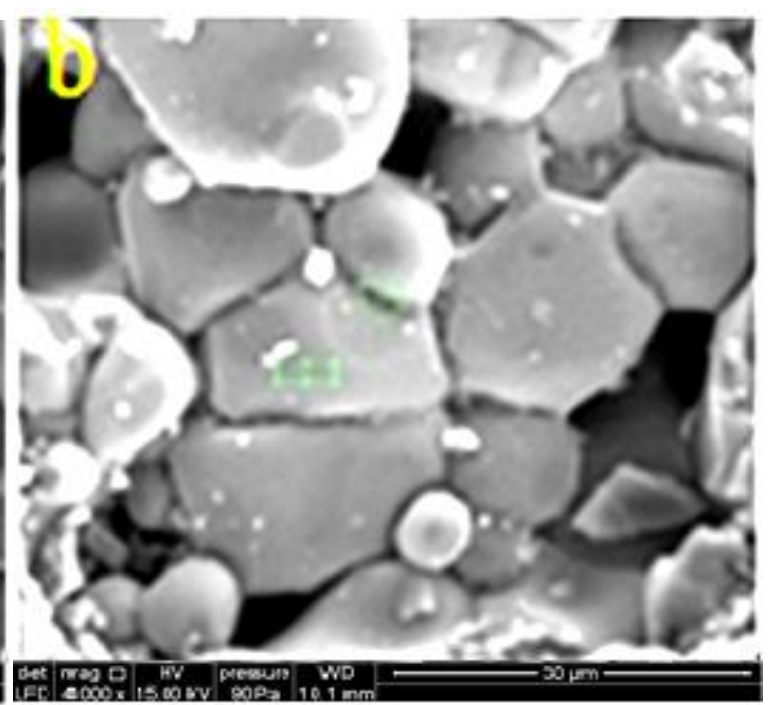

doping has a profound influence on the morphology and densification evolution of $\mathrm{CaCu}_{3} \mathrm{Ti}_{4} \mathrm{O}_{12}{ }^{26}$. The cobalt oxide is one of the compounds which have mixed valences of $\mathrm{Co}^{+2}$ and $\mathrm{Co}^{+3}$. At partial substitution of $\mathrm{Cu}^{+2}$ by $\mathrm{Co}^{+3}$, the $\mathrm{Co}^{+3}$ act as a donor impurity, for this reason, the grain growth at lower concentration is enhanced ${ }^{27}$ (as it is the case in our current samples). It is expected at or above the limit of cobalt solubility in calcium copper titanate the grain growth is inhibited because the cobalt ion has a different valence than of the copper ion and the substitution by cobalt produce a charge imbalance. 


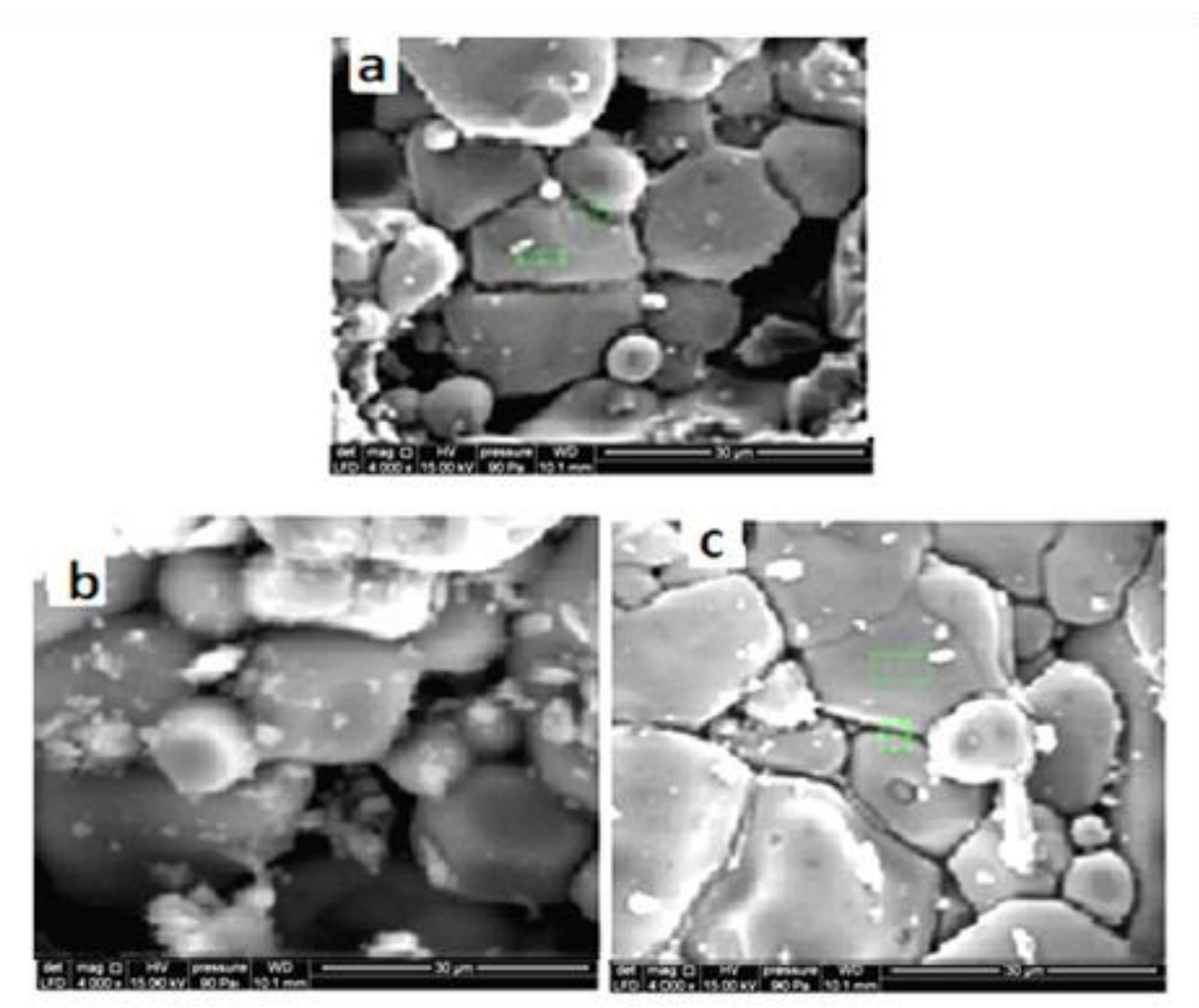

Figure 7. SEM micrographs CCCxTO pellets sintered at $1050{ }^{\circ} \mathrm{C}$ for $8 \mathrm{~h}$ obtained from powders calcined at $1050{ }^{\circ} \mathrm{C}$ for $4 \mathrm{~h}$ a) $\mathrm{x}=0.00$, b) 0.02 and c) 0.10
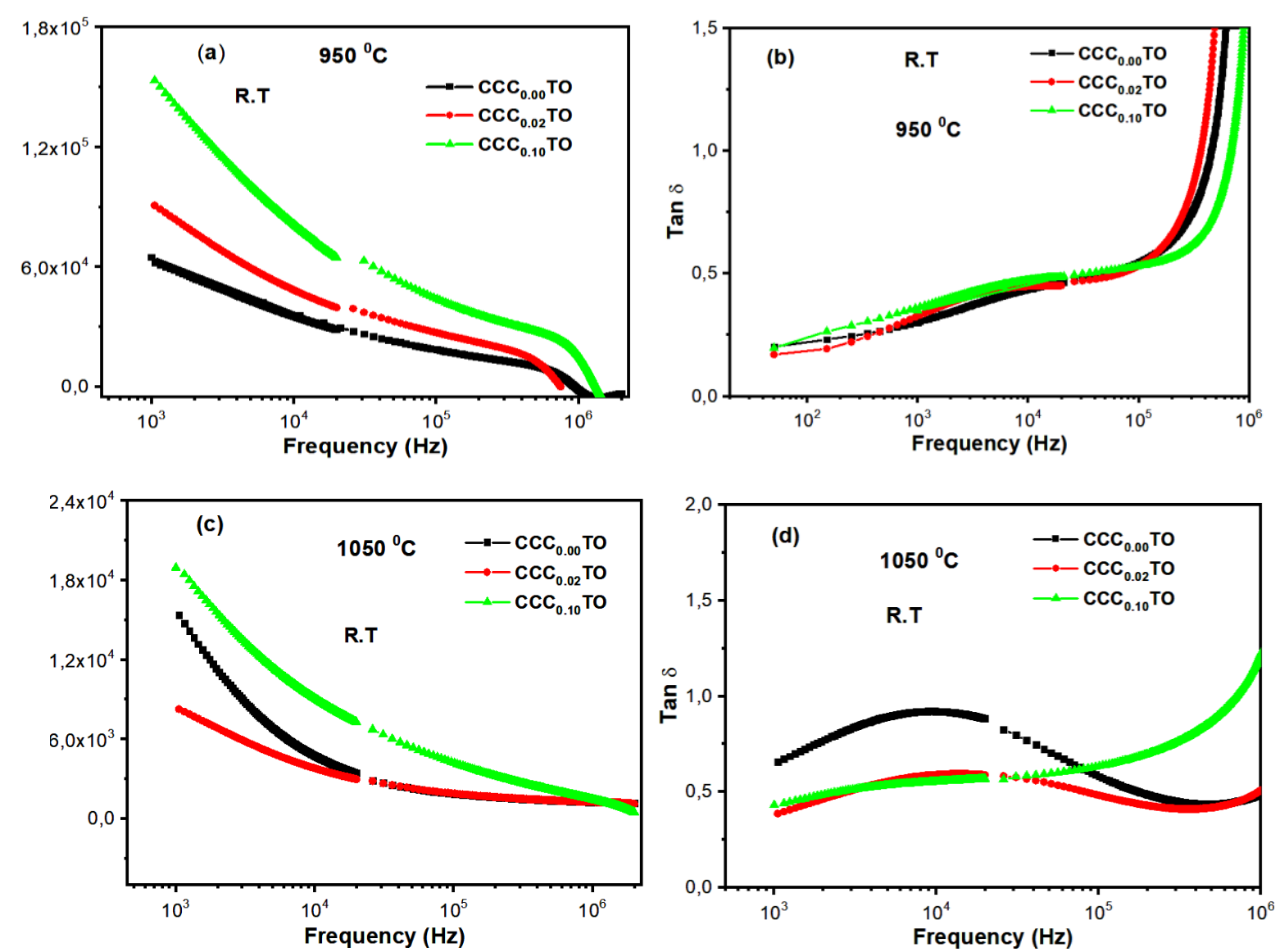

Figure 8. Real parts of the dielectric constant and dielectric loss vs of frequency at room temperature for $\mathrm{CaCu}_{3-}$ ${ }_{\mathrm{x}} \mathrm{Co}_{\mathrm{x}} \mathrm{Ti}_{4} \mathrm{O}_{12}$ ceramics calcined at several temperatures. 
In order to study and compare the dielectric behavior between samples, Fig. 8a-d shows frequency dependencies of the relative permittivity $\left(\varepsilon_{\mathrm{r}}^{\prime}\right)$ and dielectric loss $(\tan \delta)$ at room temperature. For all pure and doped samples (Fig. 8a, c and d, Table 4), the relative dielectric constants decreased with both increasing calcination temperature and frequency $(<1 \mathrm{MHz})$. We also notice from the figure a sharp drop of $\left(\varepsilon_{r}^{\prime}\right)$ with frequency; this drop is shifted to the lower frequencies with the reduction of calcination temperature, this behavior showed a typical ceramic IBLC structure for $\mathrm{CCC}_{\mathrm{x}} \mathrm{TO}$ ceramic ${ }^{28}$. On the other hand, the Fig. 8 shows the variation of the dielectric loss vs frequency. We can observe from this figure that the doping at R.T and in the frequency range of $1 \mathrm{kHz}$ to $100 \mathrm{kHz}$ did not affect calcined samples at $950{ }^{\circ} \mathrm{C}$. When the calcination temperature increases to $1050{ }^{\circ} \mathrm{C}$, the effect of doping it observed clearly, the dielectric loss of $\mathrm{CCC}_{0.00} \mathrm{TO}$ ceramic is higher than that of $\mathrm{CCC}_{0.02} \mathrm{TO}$ and $\mathrm{CCC}_{0.10} \mathrm{TO}$ ceramic in the frequency range of $1 \mathrm{kHz}$ to $100 \mathrm{kHz}$. Above this range, $\mathrm{CCC}_{0.10} \mathrm{TO}$ presents a higher loss as illustrated in Fig. 8d. In $\mathrm{CCC}_{\mathrm{x}} \mathrm{TO} / 1050{ }^{0} \mathrm{C} \quad(\mathrm{x}=0.00,0.02$ and 0.10$)$, a dielectric loss smooth peak is observed at room temperature in the frequency range of $1 \mathrm{kHz}$ to 100 $\mathrm{kHz}$ (Fig. 8d). The presence of these peaks indicates a relaxation behavior, which can be due to the difference in the microstructural features.

Table 4. The dielectric constant and dielectric loss at $1 \mathrm{kHz}$ at room temperature for the $\mathrm{CaCu}_{3}-\mathrm{xCo}_{\mathrm{x}} \mathrm{Ti}_{4} \mathrm{O}_{12}$ ceramics calcined at 950 and $1050^{\circ} \mathrm{C}$ for $4 \mathrm{~h}$.

\begin{tabular}{|l|l|l|}
\hline Sample & Dielectric constant & Dielectric loss \\
\hline $\mathrm{CCC}_{0.00} \mathrm{TO} / 950{ }^{\circ} \mathrm{C}$ & 62430.708 & 0,31 \\
\hline $\mathrm{CCC}_{0.00} \mathrm{TO} / 1050{ }^{\circ} \mathrm{C}$ & 15360.566 & 0.66 \\
\hline $\mathrm{CCC}_{0.02} \mathrm{TO} / 950{ }^{\circ} \mathrm{C}$ & 90908.007 & 0.33 \\
\hline $\mathrm{CCC}_{0.02} \mathrm{TO} / 1050{ }^{\circ} \mathrm{C}$ & 8275.957 & 0.39 \\
\hline $\mathrm{CCC}_{0.10} \mathrm{TO} / 950{ }^{\circ} \mathrm{C}$ & 153419.208 & 0.36 \\
\hline $\mathrm{CCC}_{0.10} \mathrm{TO} / 1050{ }^{\circ} \mathrm{C}$ & 18956.720 & 0.43 \\
\hline
\end{tabular}
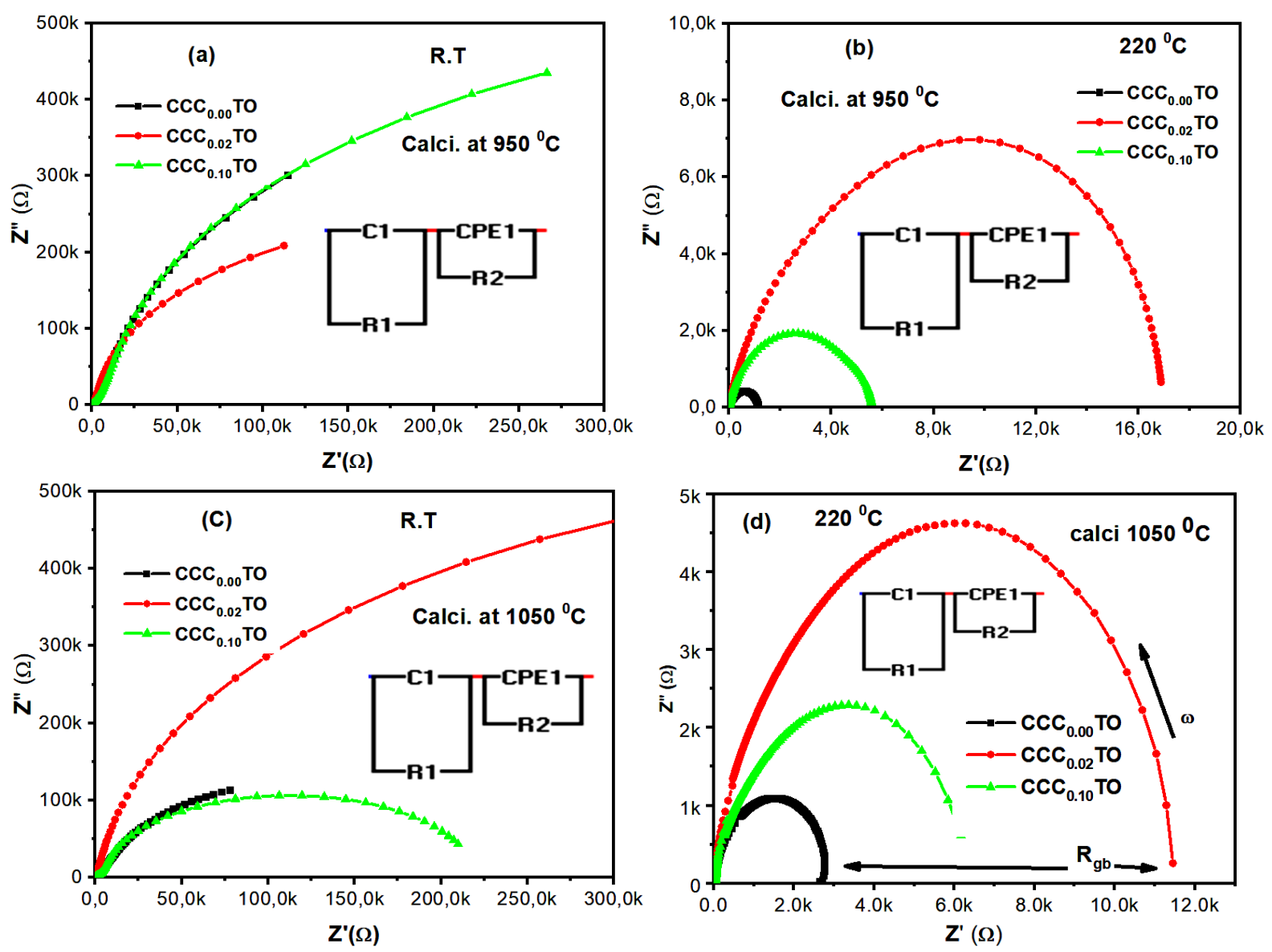

Figure 9. Nyquist plot $Z^{\prime \prime}$ vs $Z^{\prime}$ of the $\mathrm{CCC}_{\mathrm{x}} \mathrm{TO}$ ceramics calcined at different temperatures 
In order to correlate between the electrical properties of the samples to their morphologies, the capacitance and resistance associated with grain and grain boundary regions in ceramics can be estimated by impedance spectroscopy. Fig. 9 shows Nyquist plots ( $Z^{\prime}$ versus $\left.Z^{\prime \prime}\right)$ for $\mathrm{CCC}_{\mathrm{x}} \mathrm{TO}$ ceramics calcined at $950{ }^{\circ} \mathrm{C}$ and $1050{ }^{\circ} \mathrm{C}$. Measurements are made in the frequency range from $50 \mathrm{~Hz}$ to $2 \mathrm{MHz}$ at room temperature and $220{ }^{\circ} \mathrm{C}$. For all calcination temperatures, the impedance spectrum of $\mathrm{CCC}_{\mathrm{x}} \mathrm{TO}$ (pure and doped) is characterized by only one semicircle arc with a radii that decrease with increasing temperature. The semicircle should be attributed to grain-boundary response, and the diameter of the semicircle can approximately be equal to grain-boundary resistance ${ }^{29,30}$.

Accordingly, the resistance decreases with rising in temperature, which may be related to the negative temperature coefficient of resistance (NTCR) indicating a typical semiconducting behavior of the ceramics consistent with a Schottky barrier response. The resistance changes with Co doping concentration and calcination temperatures obeying a semiconductor behavior. The semicircle arcs obtained in our results could be represented by two equivalent circuits consisting of parallel combinations of both resistance and capacitance representing the semiconducting grains and the other representing the insulating grain boundary regions. The inset in the figures shows those equivalent circuits. Comparable results have been observed for $\mathrm{Y}$ doped CCTO, where $\mathrm{Y}$ is an acceptor, and thus an increase in the grain and grain boundary resistance were observed 31,32

In order to detect the effect of the smallest capacitance and the largest resistance and to distinguish whether a relaxation process is due to short or long-range movement of charge carriers in the $\mathrm{CCC}_{\mathrm{x}} \mathrm{TO}$ samples, the electric modulus $\mathrm{M}^{\prime \prime}$ and the imaginary part $Z^{\prime \prime}$ of the complex impedance evolution on the frequency are presented in Fig. 10. The figure shows two peaks for the $\mathrm{Z}$ " and modulus M". A higher peak (beyond $1 \mathrm{MHz}$ ) is correlated with the bulk grain component of the samples, and a lower frequency peak (between $1 \mathrm{KHz}$ and $100 \mathrm{KHz}$ ) is linked to the grain boundary relaxation. M" lowfrequency peaks amplitude decrease with Co amount increasing for both samples calcined at $950{ }^{\circ} \mathrm{C}$ and $1050{ }^{\circ} \mathrm{C}$. We can observe a shift of these peaks toward low frequencies and an increasing of their maximum amplitudes for sample calcined at 1050 ${ }^{\circ} \mathrm{C}$. The same results were obtained by a Dc Bias on pure and doped $\mathrm{CCTO}^{33}$.

The increase of low-frequency peaks amplitude indicates a slight decrease of the capacitance of grain boundaries due to the higher temperature of calcination, while the increasing of the Co dopant concentration increases the capacitance. We can also see on the Figures 10 ( $a$ and $b$ ) an overlapping of peaks between of $\mathrm{Z}^{\prime \prime}$ and $\mathrm{M}$ " which indicates a longrange conductivity phenomena ${ }^{34}$.
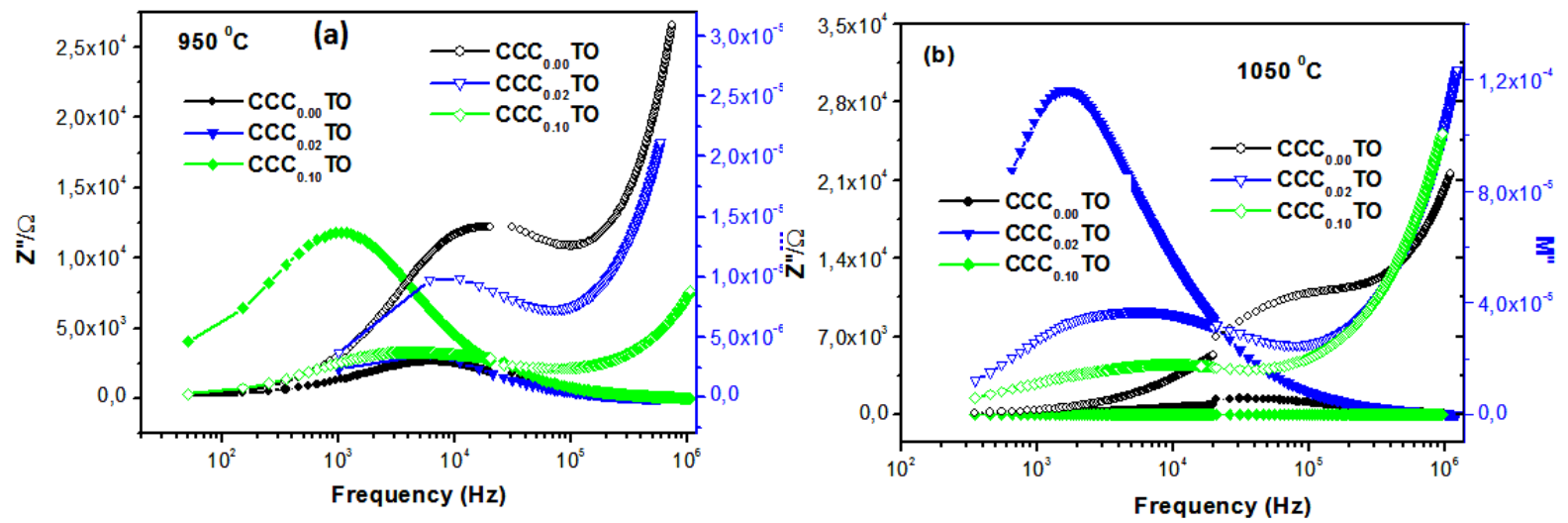

Figure 10. Bode plots of $\mathrm{Z}^{\prime \prime}$ and $\mathrm{M}^{\prime \prime}$ as a function of frequency at $220^{\circ} \mathrm{C}$ for CCCXTO samples calcined at a) $950{ }^{\circ} \mathrm{C}$ and b) $1050{ }^{\circ} \mathrm{C}$

The ac conductivity study is a useful technique for investigating the charge carrier's nature in electroceramic materials. The ac electrical conductivity was obtained from dielectric spectroscopy. The plot of electrical conductivity versus frequency at room temperature of the $\mathrm{CCC}_{\mathrm{x}} \mathrm{TO}$ samples calcined at $950{ }^{\circ} \mathrm{C}$ and $1050{ }^{\circ} \mathrm{C}$ is shown in Fig. 11. The conductivity of the ceramic exhibited four different frequency regions; these regions can be observed when the calcination temperature of the doped samples is increased from $950{ }^{\circ} \mathrm{C}$ to $1050{ }^{\circ} \mathrm{C}$. At room temperature, the conductivity follows the power law dependence on two stages (double power law). This conduction behaviour is more pronounced for the compounds calcined at $1050{ }^{\circ} \mathrm{C}$ and for highly doped $\mathrm{CCC}_{0.1} \mathrm{TO}$. This confirms the existence of two relaxation processes in these ceramics. 

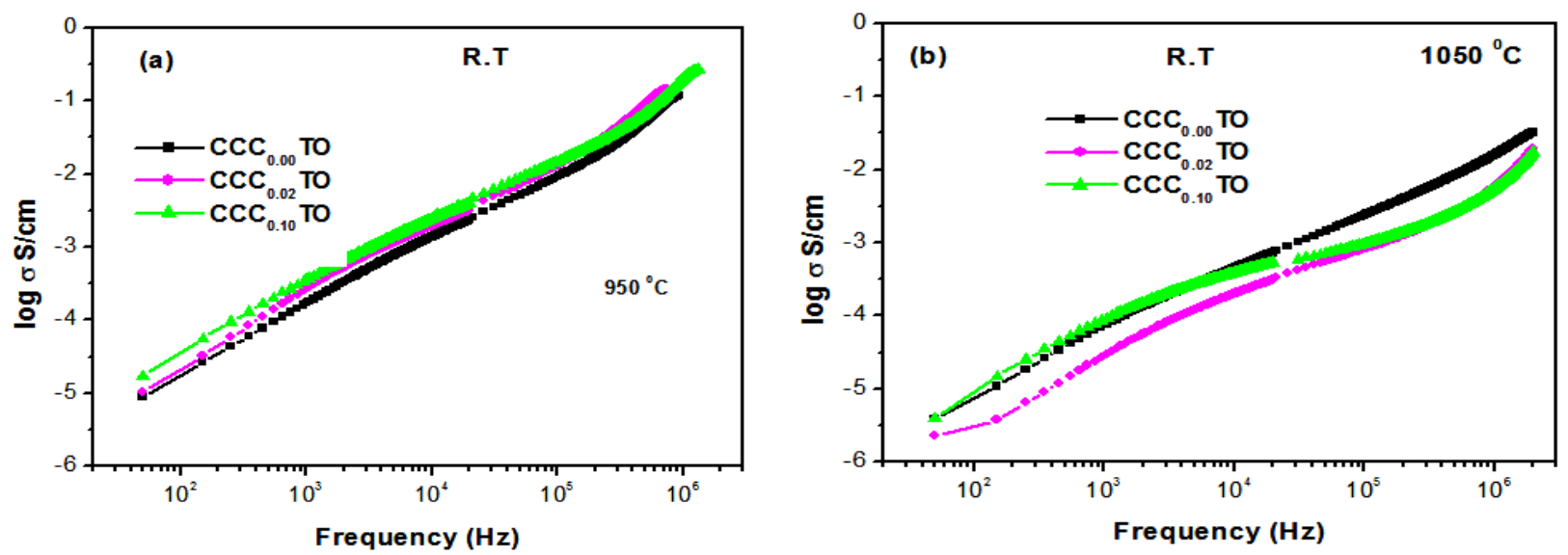

Figure 11. AC conductivity vs frequency at room temperature for the $\mathrm{CaCu}_{3-\mathrm{x}} \mathrm{Co}_{\mathrm{x}} \mathrm{Ti}_{4} \mathrm{O}_{12}$ ceramics calcined at a) $950{ }^{\circ} \mathrm{C}$ and b) $1050{ }^{\circ} \mathrm{C}$

\section{Conclusion}

The polycrystalline samples of $\mathrm{CaCu}_{3-\mathrm{x}} \mathrm{Co}_{\mathrm{x}} \mathrm{Ti}_{4} \mathrm{O}_{12}$ $(\mathrm{x}=0.00,0.02$ and 0.10$)$ were studied. The effects of the temperature of calcinations and Co-dopant concentration were found to alter the structural, morphology, dielectric and electrical properties of CCTO at different extents. The XRD patterns showed obvious no difference in pure and Co-doped CCTO spectrum at all calcination temperatures. This indicates that the crystal structure of CCTO is unchanged, while it indicated the increase of crystalline sizes with increasing in both calcination temperature and lattice constant with increasing in Co content. From SEM observations, we can conclude that the temperature calcination and doping promotes an increase of samples grain size. The $\mathrm{CCC}_{0.10} \mathrm{TO}$ at $950^{\circ} \mathrm{C}$ ceramics show higher dielectric constant and improvement of the dielectric behavior due to a super exchange interaction between aliovalent $\mathrm{Co}$ and $\mathrm{Cu}$ ions, and lower dielectric loss in the frequency range up to $10^{5} \mathrm{~Hz}$ in Co-doped CCTO calcined at $1050{ }^{\circ} \mathrm{C}$. The complex impedance analysis of the material reveals the dominance of the grain effect and grain boundary. The Z" values decrease with increasing temperature indicating a decrease of the grain and grain boundary resistance. This indicates a NTCR in all samples, which could be due to an increasing of the concentration of oxygen vacancy in grain. The doped compounds present mixed valences of $\mathrm{Co}^{+2}$ and $\mathrm{Co}^{+3}$. At partial substitution of $\mathrm{Cu}^{+2}$ by $\mathrm{Co}^{+3}$, the $\mathrm{Co}^{+3}$ act as donor impurity and have a negative influence on the dielectric losses. The Co doping and the increase of calcination temperature have a similar effect on the conductivity of CCTO at room temperature.

\section{References}

1- B.S. Prakash, K.B.R.Ã. Varma, Synthesis of the Giant Dielectric Constant Material $\mathrm{CaCu}_{3} \mathrm{Ti}_{4} \mathrm{O}_{12}$ by Wet-Chemical Methods.,2007, 180, 19181927.

2- T. Badapanda, R. Harichandan, S. Nayak, A. Mishra, S. Anwar, Frequency and temperature dependence behaviour of impedance, modulus and conductivity of $\mathrm{BaBi}_{4} \mathrm{Ti}_{4} \mathrm{O}_{15}$ aurivillius ceramic, Process. Appl. Ceram., 2014, 8, 145153.

3- W. Li, R.W. Schwartz, Ac conductivity relaxation processes in $\mathrm{CaCu}_{3} \mathrm{Ti}_{4} \mathrm{O}_{12}$ ceramics: Grain boundary and domain boundary effects, Appl. Phys. Lett., 2006, 89, 87-90.

4- V.S. Vinila et al. X-Ray Diffraction Analysis of Nano Crystalline Ceramic $\mathrm{PbBaTiO}_{3}$, Cryst. Struct. theory Appl., 2014, 3, 57-65.

5- N. Hadi. T. Lamcharfi. F. Abdi, A. Elbasset. Effect of Sintering Temperature on the Dielectric and Microstructure Properties of $\mathrm{CaCu}_{3} \mathrm{Ti}_{3,90} \mathrm{Co}_{0,10} \mathrm{O}_{12}$ Ceramic, Int. J. Dev. Res, 2017, 04, 12432-12436.

6- P.R. Bueno, W.C. Ribeiro, M.A. Ramírez, J.A. Varela, E. Longo. Separation of dielectric and space charge polarizations in $\mathrm{CaCu}_{3} \mathrm{Ti}_{4} \mathrm{O}_{12}$ $\mathrm{CaTiO}_{3}$ composite polycrystalline systems. Appl. Phys. Lett., 2007, 90, 2005-2008.

7- M.A. Subramanian, A.W. Sleight. $\mathrm{ACu}_{3} \mathrm{Ti}_{4} \mathrm{O}_{12}$ and $\mathrm{ACu}_{3} \mathrm{Ru}_{4} \mathrm{O}_{12}$ perovskites: High dielectric constants and valence degeneracy. Solid State Sci., 2002, 4, 347-351.

8- N. Hadi et al. Structural, dielectric and electrical properties of (1-x) $\mathrm{CaCu}_{3} \mathrm{Ti}_{4} \mathrm{O}_{12}$ $\mathrm{xBaTiO}_{3}$ ceramics. Asian J. Chem., 2017, 29, 1811-1816.

9- M. A. Subramanian, D. Li, N. Duan, B. A. Reisner, and A. W. Sleight, J. Solid State Chem. 2000, 151, 323

10- L. He, J. B. Neaton, M. H. Cohen, D.

Vanderbilt, C. C. Homes, First-principles study of the structure and lattice dielectric response of CaCu3Ti4O12. Physical Review B., 2002, 65, 214112. 
11- C.C. Homes, T. Vogt, S.M. Shapiro, S. Wakimoto, M.A.Subramanian, A.P. Ramirez, Charge transfer in the high dielectric constant materials $\mathrm{CaCu}_{3} \mathrm{Ti}_{4} \mathrm{O}_{12}$ and $\mathrm{CdCu}_{3} \mathrm{Ti}_{4} \mathrm{O}_{12}$, Physical Review B.,2003, 67, 092106.

12- M. H. Cohen, J. B. Neaton, L. He, D. Vanderbilt, Extrinsic models for the dielectric response of $\mathrm{CaCu}_{3} \mathrm{Ti}_{4} \mathrm{O}_{12}$. Journal of Applied physics.,2003, 94, 3299-3306.

13- C.C. Homes, T. Vogt, S.M. Shapiro, S. Wakimoto, Optical response of highdielectric-constant perovskite-related oxideA. P. Ramirez, Science., 2001, 293, 673-676.

14- D.C. Sinclair, T.B. Adams, F.D. Morrison, A.R. West, $\mathrm{CaCu}_{3} \mathrm{Ti}_{4} \mathrm{O}_{12}$ : one-step internal barrier layer capacitor, Appl. Phys. Lett., 2002, 80, 2153-2155.

15- T. B. Adams, D. C. Sinclair, A. R. West, Giant barrier layer capacitance effects in $\mathrm{CaCu}_{3} \mathrm{Ti}_{4} \mathrm{O}_{12}$ ceramics Adv. Mater.,2002, 14, 1321-1323.

16- B. Timothy. Adams, C. Derek. Sinclair, and Anthony R. West, Characterization of grain boundary impedances in fine-and coarse-grained $\mathrm{CaCu}_{3} \mathrm{Ti}_{4} \mathrm{O}_{12}$ ceramics, Physical review B., 2006, 73, 094124.

17- S. Y. Chung, I. D. Kim, S. J. L. Kang, Strong nonlinear current-voltage behaviour in perovskite-derivative calcium copper titanate Nat. Mater.,2004, 3, 774-778.

18- P. Leret, J.F. Fernandez, J.de Frutos, D. Fernndez-Hevia, Nonlinear I-V electrical behaviour of doped $\mathrm{CaCu} 3 \mathrm{Ti} 4 \mathrm{O} 12$ ceramics, J. Eur. Ceram. Soc., 2007, 27, 3901-3905.

19- S. Y. Chung, J. H. Choi, J. K. Choi, Tunable current-voltage characteristics in polycrystalline calcium copper titanate. Appl. Phys. Lett.,2007, 91, 091912.

20- J. H. Clark, M. S. Dyer, R. G. Palgrave, C. P. Ireland, J. R. Darwent, J. B. Claridge, M. J. Rosseinsky, Visible light photo-oxidation of model pollutants using $\mathrm{CaCu}_{3} \mathrm{Ti}_{4} \mathrm{O}_{12}$ : an experimental and theoretical study of optical properties, electronic structure, and selectivity, J. Am. Chem. Soc. 2011, 133, 1016-1032.

21 - L. Liu, H. Fan, L. Wang, X. Chen, P.Fang, Dc-bias-field-induced dielectric relaxation and ac conduction in $\mathrm{CaCu} 3 \mathrm{Ti} 4 \mathrm{O} 12$ ceramics, Philosophical Magazine., 2008, 88, 537-545.

22- L. Liu, H. Fan, P. Fang, L. Jin, Electrical heterogeneity in $\mathrm{CaCu}_{3} \mathrm{Ti}_{4} \mathrm{O}_{12}$ ceramics fabricated by sol-gel method. Solid State Communications, 2007, 142, 573-576.

23- a-L. Liu et al, an effective method to decrease dielectric loss of $\mathrm{CaCu}_{3} \mathrm{Ti}_{4} \mathrm{O}_{12}$ ceramics Journal of Alloys and Compounds, 2009469,529-534.

b- D. Xu, X. Yue, Y. Zhang, J. Song, X. Chen, S. Zhong, J. Ma, L. Ba, L. Zhang, S. Du, Enhanced dielectric properties and electrical responses of cobalt-doped $\mathrm{CaCu} 3 \mathrm{Ti} 4 \mathrm{O} 12$ thin films, Journal of Alloys and Compounds 773 (2019) 853-859.

24- R.A. Young. The Reitveld Method. International Union of Crystallography Monographs on Crystallography, Oxford University Press., 1995,5, pp. 1-38.

25- A. Monshi, M.R. Foroughi, M.R. Monshi. Modified Scherrer Equation to Estimate More Accurately Nano-Crystallite Size Using XRD. World, J. Nano Sci. Eng., 2012, 02, 154-160.

26- a- R. Jacob, H.G. Nair, J. Isac. Structural and Morphological Studies of Nanocrystalline Ceramic $\mathrm{BaSr}_{0.9} \mathrm{Fe}_{0.1} \mathrm{TiO}_{4}$. Int. Lett. Chem. Phys. Astron., 2014, 41, 100-117.

b- M. Ahmadipour · M. Arjmand · M. Fadzil Ain · Zainal, A. Ahmad · S-Y. Pung. (2019). Effect of WO3 loading on structural, electrical and dielectric properties of $\mathrm{CaCu} 3 \mathrm{Ti} 4 \mathrm{O} 12$ ceramic composites. Journal of Materials Science: Materials in Electronics.doi:10.1007/s10854-019-00992-z.

27- A.F.L. Almeida, P.B.A. Fechine, J.C. Góes, M.A. Valente, M.A.R. Miranda, A.S.B. Sombra. Dielectric properties of $\mathrm{BaTiO}_{3}(\mathrm{BTO})$ $\mathrm{CaCu}_{3} \mathrm{Ti}_{4} \mathrm{O}_{12}(\mathrm{CCTO})$ composite screen-printed thick films for high dielectric constant devices in the medium frequency (MF) range. Mater. Sci. Eng. B Solid-State Mater. Adv. Technol., 2004, 111, 113-123.

28- L. Singh, U.S. Rai, A.K. Rai, K.D. Mandal. Sintering effects on dielectric properties of $\mathrm{Zn}$ doped $\mathrm{CaCu}_{3} \mathrm{Ti}_{4} \mathrm{O}_{12}$ ceramic synthesized by modified sol-gel route. Electron. Mater. Lett.,2013, 9, 107-113.

29- L. Guizhong, Z. Chen, S. Xiaojun, L. Liu, L. Fang, B. Elouadi, Electrical properties of $\mathrm{AC}_{3} \mathrm{~B}_{4} \mathrm{O}_{12}$-type perovskite ceramics with different cation vacancies, Materials Research Bulletin., 2015, 65, 260-265.

30- L. Liu, L. Fang, et al. Dielectric and nonlinear current-voltage characteristics of rare-earth doped $\mathrm{CaCu}_{3} \mathrm{Ti}_{4} \mathrm{O}_{12}$ ceramics. Journal of Applied Physics., 2011, 110, 094101.

31- J. Deng, L. Liu, X. Sun, S. Liu, et al, Dielectric relaxation behavior and mechanism of $\mathrm{Y}_{2 / 3} \mathrm{Cu}_{3} \mathrm{Ti}_{4} \mathrm{O}_{12}$ ceramic Materials Research Bulletin, 2017, 88, 320-329.

32- a- J. Deng, X. Sun, S. Liu, L. Liu, et al Influence of interface point defect on the dielectric properties of $\mathrm{Y}$ doped $\mathrm{CaCu} 3 \mathrm{Ti}_{4} \mathrm{O}_{12}$ ceramics Journal of Advanced Dielectrics, 2016, 6, 1650009.

b- Pengfei, Cheng, Zhuang Cao, MinZhou, Qiuping Wang, Shengtao Li, Jianying Li, Dielectric properties of $\mathrm{CaCu} 3 \mathrm{Ti} 4 \mathrm{O} 12$ ceramics doped by La3+, Ceramics International, (2019), doi:https://doi.org/10.1016/ j. ceramint.2019.05.023.

33- a-L. Liu, Y. Huang, Y. Li, D. Shi, Sh. Zheng, Sh. Wu, L. Fang, Ch. Hu, Dielectric and non- 
Ohmic properties of $\mathrm{CaCu} 3 \mathrm{Ti} 4 \mathrm{O} 12$ ceramics modified with $\mathrm{NiO}, \mathrm{SnO}_{2}, \mathrm{SiO}_{2}$, and $\mathrm{Al}_{2} \mathrm{O}_{3}$ additives, J Mater Sci 2012, 47:2294-2299.

b- J. Boonlakhorn, B. Putasaeng, P. Thongbai. Origin of significantly enhanced dielectric response and nonlinear electrical behavior in Ni2+-doped CaCu3Ti4O12: Influence of DC bias on electrical properties of grain boundary and associated giant dielectric properties.
Ceramics International, Volume 45, Issue 6, 15 April 2019, Pages 6944-6949.

34- R. Gerhardt, Impedance and dielectric spectroscopy revisited: distinguishing localized relaxation from long-range conductivity. J. Phys. Chem. Solids., 1994, 55, 1491-1506. 